
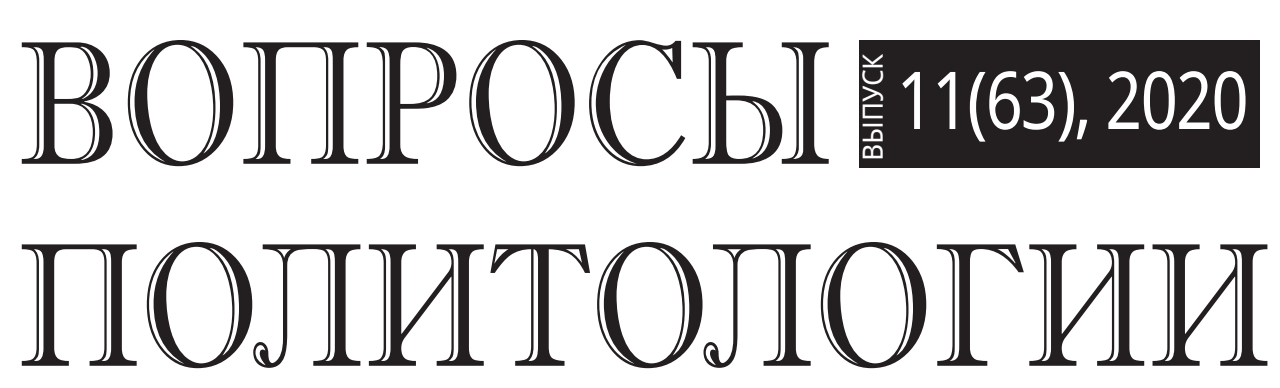

Научный журнал

Журнал «Вопросы политологии» включен

в Перечень рецензируемых научных изданий

BAK Министерства образования и науки РФ по политическим наукам, в которых должны быть опубликованы основные научные результаты на соискание ученой степени кандидата наук,

на соискание ученой степени доктора наук

Журнал включен в Перечень научных изданий рекомендованных ВАК Республики Узбекистан для публикации основных научных результатов диссертаций по политическим и философским наукам 
Председатель Редакционного Совета - ПЛАТОНОВ В.М.,

К.ю.н., заведующий кафедрой политического анализа и управления РУДН, Председатель Московской городской Думы (1994-2014 гг.)

\section{Редакционный Совет}

\section{АСТВАЦАТУРОВА}

Майя Арташесовна

БОЖАНОВ

Владимир Александрович

ВЕДРИН

Оливье

ДОНАЙ

Лукаш

ЖИЛЬЦОВ

Сергей Сергеевич

ИРХИН

Юрий Васильевич

\section{КАРАДЖЕ}

Татьяна Васильевна

КЕТЦЯН

Григор Ваникович

\section{КОВАЛЕНКО}

Валерий Иванович

КРИВОКАПИЧ

Борис

МЕДВЕДЕВ

Николай Павлович

МИХАЙЛОВ

Вячеслав Александрович

\section{НАСИМОВА}

Гульнара Орленбаевна

\section{НИСНЕВИЧ}

Юлий Анатольевич

Шукритдин Ильясович

\section{ПЛЯЙС}

Яков Андреевич

ПРЯХИН

Владимир Федорович

ПУСЬКО

Виталий Станиславович

\section{ХОПЁРСКАЯ}

Лариса Львовна

\section{ПАХРУТДИНОВ}

д.п.н., профессор, директор Центра этнополитических исследований, профессор кафедры креативноинновационного управления и права Пятигорского государственного университета, координатор Сети этнологического мониторинга и раннего предупреждения конфликтов в СКФО (Россия, г. Пятигорск)

д.и.н., профессор, зав. кафедрой мировой и отечественной культуры Белорусского Национального технического университета (Белоруссия, г. Минск)

профессор, главный редактор русской версии французского журнала «Национальная оборона» (Revue Défense Nationale), спикер Европейской комиссии, редактор франко-германского журнала по вопросам внешней политики «European Union Foreign Affairs Journal» и ректор «Континентального университета в Киеве» (Франция, г. Париж)

Д.п.н., профессор факультета политологии и журналистики Департамента международных отношений Университета им. Адама Мицкевича в Познани (Польша, г. Познань)

д.п.н., заведующий кафедрой политологии и политической философии Дипломатической академии МИД РФ (Россия, г. Москва)

д.ф.н., профессор кафедры политологии и политического управления РАНХ и ГС при Президенте РФ (Россия, г. Москва)

д.ф.н., заведующая кафедрой политологии и социологии МПГУ (Россия, г. Москва)

к.П.Н., заместитель Главного редактора журнала, Председатель Попечительского Совета научного журнала «Вопросы политологии» (Россия, г. Москва) д.ф.н., зав. кафедрой российской политики МГУ им. М.В. Ломоносова (Россия, г. Москва)

д.ю.н., профессор факультета бизнеса и права Унион Никола Тесла университета (Сербия, Белград)

д.п.н., профессор кафедры анализа и управления Российского университета дружбы народов, главный редактор журнала (Россия, г. Москва) д.и.н., зав. кафедрой национальных и федеративных отношений РАНХ и ГС при Президенте РФ (Россия, г. Москва)

д.п.н., профессор, зав. кафедрой политологии факультета философии и политологии Казахского Национального университета им. Аль-Фараби (Казахстан, г. Алматы) д.п.н., профессор Национального исследовательского университета «Высшая школа экономики» (Россия, г. Москва)

д.п.н., профессор, заведующий кафедрой основы духовности Института переподготовки и повышения квалификации руководителей и специалистов системь народного образования имени А. Авлони (Узбекистан, г. Ташкент)

д.и.н., д.п.н., профессор Финансового университета при Правительстве РФ (Россия, г. Москва)

д.п.н., профессор кафедры зарубежного регионоведения и внешней политики РГГУ (Россия, г. Москва)

д.ф.н., профессор кафедры гуманитарных дисциплин ВА РВСН им. Петра Великого (Россия, г. Москва)

д.п.н., профессор кафедры международных отношений Киргизско-Российского славянского университета, (Киргизия, г. Бишкек)

\section{Редакционная коллегия}

Главный редактор - МЕДВЕДЕВ Н.П., д.П.н., профессор

Абрамова О.Д. (д.п.н.)

Насимова Г.О. (д.п.н.)

Кетцян Г.В. (к.п.н. - зам. гл. редактора)
ISSN 2225-8922

ЖУРНАЛ ВКЛЮЧЕН В ПЕРЕЧЕНЬ ВАК РФ

\section{УЧРЕЖДЕН}

ООО «Издательство «Наука сегодня»

Журнал зарегистрирован

Федеральной службой по надзору в сфере массовых коммуникаций, связи и охраны культурного наследия

\section{Рег. № ПИ № ФС77-46176} от 12 августа 2011 г.

Журнал издается ежемесячно

Журнал включен в базу РИНЦ (Российский индекс научного цитирования)

Включен в каталог Ulrich's Periodicals Directory

Пятилетний импакт-фактор: 1,489.

Адрес редакции: 115598 , г. Москва, ул. Загорьевская, д. 10, корп. 4, цокольный этаж, помещение I, комната 7-1, офис 4 Тел.: (910) 463-53-42

Интернет-ресурс: www.voprospolitolog.ru E-mail: voprospolitolog@yandex.ru

Мнение авторов может не совпадать с мнением редакции. При перепечатке ссылка на журнал обязательна.

Научные статьи, публикуемые в журнале подлежат обязательному рецензированию.

Ответственный редактор Шкурина С.С.

Перевод

Чернышова Е.В.

Компьютерная верстка Анциферова А.С.

Подписано в печать 26.11.2020

Формат 60×84/8. Объем 24,3.

Печать офсетная.

Тираж - 1000 экз.

(1-й завод - 500 экз.) Заказ № 0000.

Отпечатано в типографии PrintUP 117105 , г. Москва, Нагорный проезд, 12, корп. 1 Тел.: +7 (495) 925-00-06 
ISSN 2225-8922 (print)

12 выпусков в год и

4 выпуска в год переводной (англ.) версии

Языки: русский, английский

http://voprospolitolog

Входит в перечень рецензируемых научных изданий ВАК РФ Включен в каталог периодических изданий Ульрих

(Ulrich's Periodicals Directory: http://www.ulrichsweb.com)

Материалы журнала размещаются на платформе РИНЦ

Российской научной электронной библиотеки, Electronic Journals Library Cyberleninka

Подписной индекс издания в каталоге агентства Роспечать 70035

\section{Цели и тематика}

Журнал ВОПРОСЫ ПОЛИТОЛОГИИ - периодическое международное рецензируемое научное издание в области политических исследований. Журнал является международным как по составу редакционного совета и редколлегии, так и по авторам и тематике публикаций.

Научный журнал издается с 2011 года в издательстве «Наука сегодня». С 2016 года издается переводная (англ.) версия журнала. С момента своего создания, журнал ориентировался на высокие научные и этические стандарта и сегодня является одним из ведущих политологических журналов России.

Цель журнала - способствовать научному обмену и сотрудничеству между российскими и зарубежными политологами.

Журнал предназначен для публикации результатов фундаментальных и прикладных научных исследований. Тематическая направленность журнала отражается в следующих постоянных рубриках: «История и философия политики», «Политические институты, процессы и технологии», «Политическая регионалистика и этнополитика», «Политическая культура и идеологии», «Политические проблемы международных отношений и глобализации».

Формат публикаций: научные статьи, обзорные научные материалы, материалы круглых столов, научные рецензии, научные сообщения, посвященные исследовательским проблемам в сфере политики и политологии.

В своей деятельности редакционный совет и редколлегия журнала руководствуется принципами, определяемыми ВАК России для научных журналов, в том числе: наличие института рецензирования для экспертной оценки качества научных статей; информационная открытость издания; наличие и соблюдение правил и этических стандартов представления рукописей авторами.

Целевой аудиторией журнала являются российские и зарубежные специалисты-политологи, а также аспиранты и магистры, обучающиеся по направлениям политология, государственное и муниципальное управление и международные отношения.

Журнал строго придерживается международных стандартов публикационной этики, обозначенных в документе СОРЕ (Committee on Publication Ethics) http://publicationethics.org

Полные сведения о журнале и его редакционной политике, требования о подготовке и публикации статей, архив (выпуски c 2011 года) и дополнительная информация размещена на сайте: http://voprospolitolog.ru

Электронный адрес: voprospolitolog@yandex.ru

ISSN 2225-8922 (print)

12 issues a year plus 4 issues a year of the translated (eng.) version Languages: Russian and English http://voprospolitolog

Included in the list of peer-reviewed scientific publications of the Higher Attestation Commission of the Russian Federation Included in the Ulrich's Periodicals Directory Materials of the journal are placed on the RSCI platform of the Russian scientific electronic library - Electronic Journals Library Cyberleninka Subscription index of the journal in the Rospechat Agency catalogue is: 70035

\section{Objectives and themes}

Academic journal "Political Science Issues" is an international peer-reviewed scientific periodical in the field of political studies. The journal has an international character because of the composition of its Editorial Board, its editors, its contributing authors and topics of its publications.

The scientific journal is published since 2011 at the "Publishing House "Science Today". Translated (eng.) version of the journal is published since 2016. Since its inception, the journal was guided by high scientific and ethical standards and today it is one of the leading political science journals in Russia.

The purpose of the journal is to promote scientific exchange and cooperation between Russian and foreign political scientists.

The journal is intended for the publication of the results of fundamental and applied scientific research. Thematic focus of the journal is reflected in the following permanent headings: "History and philosophy of politics," "Political institutions, processes and technologies," "Political regionalism and ethno-politics," "Political culture and ideologies," "Political problems of international relations and globalization."

Format of publications: scientific articles, reviews, scientific materials, materials of round tables, scientific reviews, scientific reports devoted to research problems in the field of politics and political science.

The Editorial Board and the editors of the journal in their activities are guided by the principles defined by VAK of Russia for scientific journals, including: presence of the institute of peer review for the expert quality assessment of scientific articles; information openness of the publications; availability and compliance with the rules and ethical standards for the submission of manuscripts by the authors.

The target audience of the journal is Russian and foreign specialists-political scientists, as well as graduate students and masters in the fields of political science, state and municipal management and international relations.

The journal strictly adheres to the international publishing standards and publication ethics identified in the COPE (Committee on Publication Ethics) document. http://publicationethics.org.

Full details of the journal and its editorial policy, requirements to the preparation and publication of articles, archive (issues since 2011) and additional information are available on the website: http://voprospolitolog.ru

E-mail address: voprospolitolog@yandex.ru 


\section{ТЕОРИЯ, ФИЛОСОФИЯ И ИСТОРИЯ ПОЛИТИКИ}

Аствацатурова М.A. «Северокавказское имагинарное»

в социальной сущностно-функциональной этике

политического управления

Грудина T.H. Константы религиозного и политического учения

С.Л. Франка: социально-философский анализ.

\section{ПОЛИТИЧЕСКИЕ ИНСТИТУТЫ, ПРОЦЕССЫ И ТЕХНОЛОГИИ}

Назаров А.Д., Назарова Е.А. Особенности интеграции

беспилотных летательных аппаратов в сферу гражданской авиации:

политико-правовые аспекты

Прончев Г.Б., Михайлов А.П. Подходы к изучению

и моделированию кланов как фактора политической системы .

Бродская Н.П. Искусственный интеллект: попытки применения

в социальном пространстве и проблемы адаптации.

Галиева С.И., Галиева Г.М. Оценка эффективности институциональной системы реализации государственной политики по профилактике преступности и меры по ее совершенствованию

Амиантова И.С. Факторы успеха партии «Новые люди»

в ходе региональных выборов 2020 г. в России

Maйcmam M.A. Эндогенный период в развитии российской

многопартийности (1991-1999 гг.): «апоритивный синдром»

By $\boldsymbol{T} \boldsymbol{x} \boldsymbol{u}$ Xыюнг. Праймериз как PR-инструмент мобилизации граждан

в рамках электорального процесса


политической элиты: на примере президентских кампаний (2010-2019)

Аветисян A.C. Система политического менеджмента корпораций в общем цикле принятия и реализации стратегических решений

Голофаст A.B. Политические процессы

в цифровую эпоху: междисциплинарный синтез

Ильин И.С. Взаимодействие государственной власти

Российской Федерации и Русской Православной церкви

в условиях усложнения эпидемиологической обстановки в мире

Зверева М.В., Новикова А.В., Попов С.И. Проблемы государственного регулирования социально-экономического развития и управления в московской агломерации. Пути решения

Махрамов У.Ш. Коммуникативная тактика

и стратегия справедливости общества. 
Агурова А.А., Тихонова А.В. Анализ активности

политических партий на платформе социальных сетей

в контексте предвыборной кампании 2021 года.

ПОЛИТИЧЕСКАЯ ПСИХОЛОГИЯ, КУЛЬТУРА И ИДЕОЛОГИИ

Сабирова Н.С. Гражданское общество

как аспект современной политической культуры России

Зубова О.Г. Особенности ценностной структуры молодежи

в современном российском обществе

Имомов Э.И. Духовная среда:

содержание, аспекты и основы формирования

ПОЛИТИЧЕСКАЯ КОНФЛИКТОЛОГИЯ

Зазнаев О.И., Сидоров В.В. Взаимосвязь форм государственного

правления и этнических конфликтов: статистический анализ

\section{МЕЖДУНАРОДНЫЕ ОТНОШЕНИЯ И МИРОВАЯ ПОЛИТИКА}

Магадиев М.Ф. Санкционная политика ведущих стран мира

в отношении Российской Федерации: угрозы и основные направления противодействия

Шалыгина Н.В., Снежкова И.А. Молодежь как перспективный ресурс российско-белорусской интеграции..

Равочкин H.H. Анализ причин неудачного заимствования

передового политико-правового институционального опыта

странами Африки и Латинской Америки

Аниськевич Н.C. Чили и Тихоокеанский альянс: новые векторы взаимодействия 3268

Зубов В.В., Родионова М.Е., Ульянов Д.В. Перспективы российско-американских отношений в контексте политики, проводимой администрацией президента Трампа, и ее влияния на преобразование американской конъюнктуры. 3276

Данюк Н.С., Сенокоп Я.С. «Цветные революции» как инструмент гибридных технологий во внешней политике 3288

Капитонов А.A. Смена парадигмы развития:

экологический фактор в прошлом, настоящем и будущем 3298

Сарсембаев Н.B. Развитие сирийского конфликта: от требований демократических преобразований к религиозно-мотивированному террору 
Гомелаури А.C. К вопросу восприятия феномена «мягкой силы» в контексте российской внешней политики 3316

Ло Линянь. Феномен глобального лидерства в мировой политике 3324

Шоимов А. Основные направления политики взаимодействия гражданского общества и государства на новом этапе национального развития Узбекистана.

Юдин H.O. Культурная политика Газпрома: внутриполитические и внешнеполитические аспекты.

Никуикин А.Б. Особенности электронного участия в Пиратской партии Германии 3348

Семибоков Д.А. Актуальные вопросы устойчивости политических систем непризнанных государств

\section{СТУДЕНЧЕСКАЯ НАУКА}

Пекпаева М.А. Информационное общество: современные реалии и проблемы развития. 3364

Гришин B.O. Развитие железнодорожного пассажирского транспорта Московской области: проблемы и перспективы социально-политического проектирования ..

\section{КОНФЕРЕНЦИИ}

Жигульская Д.В. Международная научно-практическая конференция молодых ученых online «Этно-социокультурные процессы в странах Азии и Африки: проблема идентичности»

НАШИ АВТОРЫ 3390 
соискатель ученой степени кандидата политических наук Дипломатической академии Министерства иностранных дел Российской Федерации, Россия, г. Москва

\section{СМЕНА ПАРАДИГМЫ РАЗВИТИЯ: ЭКОЛОГИЧЕСКИЙ ФАКТОР В ПРОШЛОМ, НАСТОЯЩЕМ И БУДУЩЕМ}

В данной статье рассматриваются господствовавиие на разных этапах становления общества подходы к развитию и роль, которую отводили в них окружающей среде, анализируется современный переходный этап от потребительского отношения к природе к рациональному использованию ее ресурсов на основе кониепции устойчивого развития, объясняются причины сохраняющихся экологических проблем и предлагаются возможные способы их решения.

Ключевые слова: общество, устойчивое развитие, глобальные вызовы, экономический рост, научно-технический прогресс, ООН, экология, ресурсы.

Устойчивое развитие является одной из существующих моделей развития человеческой цивилизации, которая характеризуется сбалансированностью социального, экономического и экологического аспектов жизнедеятельности мирового сообщества. В настоящее время под «устойчивым развитием» принято понимать «развитие, при котором удовлетворение потребностей нынешних поколений осуществляется без ущерба для возможностей будущих поколений удовлетворять свои собственные потребности» [33]. Такой подход к развитию был выработан относительно недавно: его формирование приходится по большей части на вторую половину $\mathrm{XX}$ века, а укрепление и конкретизация продолжаются и поныне. Одним из основных мотивов концепции является забота об окружающей среде, которой на определенных этапах истории уделялось мало внимания. В данной статье предлагается кратко ознакомиться с эволюцией взглядов на отношение общества к окружающей среде, проанализировать текущую ситуацию в области экологии, сложившуюся в ходе практической реализации концепции УР, рассмотреть сохраняющиеся в отношении окружающей среды проблемы и предложить возможные способы их решения.

На протяжении истории вопрос о восприятии природы человеком всегда сохранял свою актуальность. Античные философы разделяли идею цикли- 
ческого развития, то есть неминуемого возвращения космоса, частью которого являлся человек, к своему идеальному порядку, гармонии, вечности и неподвижности, что ясно представлено, например, в трудах Гераклита, Эмпедокла, Ксенофана, Парменида и др. [7]. Люди верили, что являются равной другим частью мироздания, обожествляли природу и относились к ней со страхом и уважением. В христианской философии при рассмотрении вопроса развития внимание так же преимущественно уделяется не материальной составляющей жизни общества, а духовной, где целью человека является стремление к единству с богом, что ярко отражено в трудах А. Аврелия и С. Боэция [13]. Идеи дуализма здесь так же обусловили почтительное отношение к природе как к физическому проявлению замысла Создателя. В эпоху Возрождения, несмотря на возрастающий интерес к научному знанию, человек все еще воспринимался составляющим природы, которая в трудах Н. Кузанского является проявлением бесконечного Бога. В изысканиях Л. да Винчи прослеживается идея коэволюции природы и общества на основе восполнения взятых ресурсов [5]. В эпоху Просвещения мыслителям уже было свойственно разделять «мир человека» и «мир природы», при этом благодаря разуму первый должен был главенствовать над вторым для удовлетворения собственных потребностей в стремлении к всеобщему равенству [3]. Ф. Бэкон и Р. Декарт провозглашали необходимость познания природы и расширения власти человека над ней [9], однако идеи коэволюции сохранились в воззрениях Ж.Ж. Руссо [12] и И. Канта [10]. Позже рационализм и стремление к объяснению мира все в большей степени, а затем и исключительно посредством науки, что укрепилось в идеях позитивизма О. Конта, стимулировали научно-технический прогресс, плоды которого стали стремительно внедряться в хозяйственную деятельность. С течением времени все более прочно укореняются такие идеи, как, например, «Человек - царь природы» или же «Потребление ради процветания», растет иллюзорность неисчерпаемости природных благ и богатств [2].

Так, основным мерилом прогресса становятся преимущественно экономические критерии, укрепляется потребительское отношение к окружающему миру и его ресурсам. I-я, II-я, а затем III-я НTP способствуют развитию новых производственных и добывающих отраслей, технологий, позволяющих извлекать и обрабатывать большее количество сырья. Скачок в динамике потребления был обусловлен также небывалой интенсивностью темпов роста мирового населения [20]: за относительно небольшой период с 1850 по 1930 гг. оно удвоилось с 1 до 2 млрд и продолжало все быстрее увеличиваться [23. Р. 5].

К тому времени человечество уже начало постигать печальный опыт промышленного загрязнением атмосферы, водных и земных экосистем, что непосредственно сказывалось и на жизнях людей (например, инцидент в Донора - 1948 г. [19], «Великий смог» в Лондоне - 1952 г. [36], разлив 
нефти с корабля S.S. Jacob Luckenbach - 1953 г. [34], слив отходов в реку Дзиндзу и в залив Минамата - 1950-е гг. [15], смог в Еккаити - 1956 г.).

К 1960-1970-м гг. становятся в большей степени очевиден кризис сугубо экономического мировоззрения, старой модели производства, приводивший к истощению природных ресурсов, загрязнению окружающей среды и изменению климата. Сознание людей стало меняться в сторону гуманистических взглядов, подразумевавших обеспечение равенства, достойной жизни для всех при должной заботе об окружающем мире. Работы отдельных исследователей (напр., Р. Карсон - «Безмолвная весна» 1962 г. [21], У.Р. Хиббарда «Минеральные ресурсы: вызов или угроза?» 1968 г. [26] и др.), аналитических объединений (напр., Римского клуба - «Пределы роста» 1972 г. [27], «Человечество на перепутье» 1974 г. [28] и др.), общественные выступления и акции появляющихся экологических организаций (напр., Гринписа в районе Амчитки в 1971 г., возле атолла Муруроа в 1975 г. [22] и др.) привлекли внимание государств к несостоятельности мировоззренческих ориентиров сложившейся политико-экономической системы и заставили их искать альтернативный путь развития, учитывающий, помимо экономических показателей, социальные и экологические.

Стокгольмская декларация 1972 г., включающая 26 принципов защиты окружающей среды и рационального использования ресурсов [6], доклад Комиссии по окружающей среде и развитию $\mathrm{OOH}$ «Наше общее будущее» 1987 г., сформировавший основы концепции УР [33], созданные на их базе Конвенция ООН о биологическом разнообразии 1992 г. [11], Рамочная конвенции ООН об изменении климата 1992 г., принятый к ней в 1997 г. Киотский протокол [14], стратегический документ Повестка дня на XXI век [18], Парижское соглашение по климату 2015 г. [29] и Аддис-Абебская программа действий по финансированию развития 2015 г. [1] сегодня служат единым согласованным механизмом взаимодействия государств, международных организаций, бизнеса и гражданского общества в сфере практической реализации концепции устойчивого развития. Основное значение в этом отношении имеют отраженные в документе «Преобразование нашего мира: Повестка дня в области устойчивого развития на период до 2030 года» Цели устойчивого развития (ЦУР) [17], заменившие в 2015 г. Цели развития тысячелетия (ЦРТ) 2000 г. [16]. 17 целей, 169 задач и 230 индикаторов, созданные на основе сбалансированности социального, экономического и экологического аспектов, имея взаимосвязь со всеми вышеуказанными документами, сейчас являются наиболее всеохватным инструментом для выстраивания заинтересованными сторонами собственной политики в области развития, а также для ее оценки и модернизации.

В докладе The Sustainable Development Goals Report 2020 отмечается, что, невзирая на главный бич текущей действительности - эпидемию Covid-19, пошатнувшую экономическую и политическую ситуации в мире 
и унесшую более миллиона жизней, ЦУР продолжают служить основным путем для нынешнего и грядущего общества к более справедливому, безопасному и здоровому миру для всех [37]. Социальный, экономический и экологический аспекты развития в рамках современности, согласно Повестке 2030, не могут рассматриваться отдельно по причине их абсолютной взаимозависимости, однако, принимая во внимание исторический аспект исследуемой нами проблемы, примечательно, что семь из семнадцати ЦУР, а именно ЦУР № 6, № 7, № 11, № 12, № 13, № 14 и № 15, имеют довольно ярко выраженную природоохранную составляющую, которую еще полвека назад по сути не учитывали, говоря о развитии.

ЦУР и иные принятые на международном уровне инструменты обеспечения устойчивого развития помогли добиться позитивных результатов в области защиты окружающей среды. Так, согласно докладу The Sustainable Development Goals Report 2020, доля возобновляемых источников энергии в общем конечном потреблении энергии достигла 17,3\% в 2017 г. по сравнению с 17,0\% в 2015 г. и 16,3\% в 2010 г.; за период 2000-2018 гг. глобальные выбросы парниковых газов в развитых странах и странах с переходной экономикой сократились на 6,5\%; за период 2010-2019 гг. объем вод под национальной юрисдикцией, включенных в состав охраняемых районов удвоился и составляет 24 млн квадратных километров; за период 2000-2020 гг. доля находящихся в пределах охраняемых зон ключевых районов биоразнообразия увеличилась на $12-13 \%$ и составила 44\% для наземных и 41\% для пресноводных; в период 2015-2020 гг. ежегодные темпы обезлесения составили 10 млн гектаров, что на 2 млн гектаров меньше чем в период 2010-2015 гг. [37].

В то же время продвижение в достижении ЦУР неравномерно как по сферам их охвата, так и в географическом плане, что зачастую вызвано недостатком политической воли со стороны некоторых вовлеченных в их реализацию субъектов. Большинство стран мира в публичном дискурсе поддерживают инициативы ООН по УР, однако не всегда следуют векторам, очерченным в Повестке 2030. Так, в шестом докладе ЮНЕП «Глобальная экологическая перспектива» 2019 г. говорится, что усилия в области природоохранной политики в настоящее время затруднены в силу нерациональных моделей производства и потребления в большинстве стран и изменения климата, которое также во многом носит антропогенный характер [4]. Это подтверждается и в докладе The Sustainable Development Goals Report 2020, авторы которого констатируют продолжающееся истощение природных ресурсов, повышение количества вредных выбросов в атмосферу и недостаточную защищенность водных и наземных экосистем [37].

Дело в том, что многие акторы мировой экономики, ориентируясь на прибыль в рамках сложившейся неолиберальной системы, или не обращают внимания на наличие глобальных экологических проблем, которые зачастую сами подпитывают, или заявляют о своей поддержке ЦУР, не при- 
меняя их на практике. Более того, некоторые субъекты активно противодействуют реализации концепции, пытаясь ее дискредитировать. Например, всесторонний анализ документации ExxonMobil показал, что с 1977 г. внутренние публикации ученых компании содержат в повестке вопрос об изменении климата, в то время как через платные публичные рекламные материалы она продвигает идею сомнения в подобных изменениях. Индустрия ископаемого топлива также вкладывает значительные средства в консервативные фонды и аналитические центры, которые в своих работах опровергают невыгодные этим компаниям научные наблюдения [25]. Другим примером отказа от работы над экологическими проблемами может послужить решение Д. Трампа о сокращении площади двух природоохранных зон в штате Юта для расширения там добычи полезных ископаемых: национальный памятник Bear Ears был урезан с 5 470,74 км2 на 85\% [31], а заповедная зона Grand Staircase-Escalante, изначально занимающая площадь 7610 км2, сократилась почти вдвое - на 47\% [32].

Поощряя индивидуализм, на наш взгляд, неолиберальная система замыкает как производителей, так и потребителей в колее собственных целей, лишая их интереса к групповым, общественным проблемам. Также сложившаяся система, работая на руку финансово-экономической элите, не готовой расставаться с прибылью, укрепляет общество потребления. А.Н. Ильин определяет этот феномен как «свойственный современному капиталистическому укладу тип культуры, в которой ценностно-смысловым ядром выступает символизм вещей, стимулирующий поведенческие практики демонстративной самопрезентации» [8]. В рамках неолиберализма эта практика была возведена в абсолют: потребности современного общества особенно в развитых странах искусственно завышаются, сверхпотребление преподносится обывателю как бесконечные возможности и признак экономического развития и прогресса. Для повышения прибыльности «здесь и сейчас» производители используют высокую скорость сменяемости модных трендов и намеренное уменьшение жизненного цикла вещей, что ведет к увеличению объемов использования природных ресурсов без учета темпов их возобновляемости и без принятия во внимание потребностей будущих поколений. Например, по данным Продовольственной и сельскохозяйственной организации ООН, в мире каждый год выбрасывают или уничтожают 1,3 млрд тонн произведенного и пригодного к употреблению продовольствия. Ресурсы, затраченные на его производство, тратятся впустую, в то время как с помощью лишь четвертой части от уничтоженных продуктов было бы возможно решить мировую проблему голода [35]. Ответственность отдельного человека за те или иные глобальные проблемы, как нам кажется, не принимается во внимание, и всегда находится в парадигме производителя. Примером этому могут служить юридические механизмы, предусматривающие штрафы для компаний, производящих чрезмерное ко- 
личество выбросов в атмосферу или неправильно утилизирующих отходы, издержки на оплату которых при формировании стоимости товара могут покрывать потребители, сами того не зная.

Развивающиеся страны в то же время зачастую даже в большей степени подвержены экологическим проблемам, так как мягкое законодательство в природоохранной сфере, дешевая рабочая сила и выгодные налоговые условия дают возможность использовать их как сырьевой придаток и располагать на их территориях опасные производства, что во многом обусловлено политикой Вашингтонского консенсуса, еще с начала 1990-х гг. предполагающей дерегуляцию экономики, приватизацию госсектора, а также либерализацию финансовых рынков и внешней торговли в обмен на предоставление кредитов [30].

Также следует упомянуть, что инструменты, предлагаемые ООН, для решения экологических проблем носят лишь рекомендательный характер, будучи рассчитанными на сознательность использующих их заинтересованных сторон, и в целом не предполагают каких-либо штрафных санкций за их неисполнение (кроме данных о близящемся катастрофическом ухудшении состояния планеты) или поощрений за строгое следование им (кроме прогнозов о нормализации состояния окружающей среды) в силу принципа невмешательства во внутренние дела государств, на которые, как раз, преимущественно и рассчитаны принимаемые меры по причине наличия у последних возможности более жесткого регулирования природоохранного и налогового законодательства, а вместе с тем и схем производства на местах. Однако в силу базирования экономики на сырьевом экспорте, развитых открытых или теневых лобби отраслей, на долю которых приходится основная часть загрязнения, недостатка политической воли, а также отдаленности перспектив экстремальной деградации экологической ситуации сиюминутные выгоды кажутся куда более важными, чем издержки в плане изменения нерациональных моделей потребления.

В связи с вышесказанным, возвращаясь к выводам доклада The Sustainable Development Goals Report 2020, отметим, что во многих областях, в частности экологической, по линии устойчивого развития в некоторых направлениях наблюдается не только отсутствие прогресса, но и деградация: при всех прочих равных к 2030 г. 2,3 млрд человек по-прежнему будут лишены доступа к экологически чистым видам топлива; деградация земель подрывает благосостояние примерно 3,2 млрд человек; с 2010 по 2019 гг. мировой объем электронных отходов вырос с 5,3 до 7,3 кг на душу населения в год; доля рыбных запасов в пределах биологически устойчивых уровней сократилась с 90,0\% в 1974 г. до 65,8\% в 2017 г.; доля лесных площадей в глобальном масштабе сократилась с 31,9\% в 2000 г. до 31,2\% в 2020 г.; риск исчезновения разных видов флоры и фауны за последние 30 лет возрос на 10\%; для достижения целевого показателя повышения температуры 
в $1,5^{\circ} \mathrm{C}$ выбросы парниковых газов должны с 2020 г. ежегодно снижаться на 7,6\%, однако, несмотря на резкое снижение экономической активности из-за COVID-19, полученное в результате годовое сокращение выбросов составило $6 \%$ [37].

В нынешних условиях представляется трудным одномоментно поставить мировую экономику на рельсы устойчивого развития в силу описанных нами выше причин, заключающихся в доминировании личных интересов над коллективными, однако сейчас картина такова, что от этих общих интересов по сути зависит физическое существование человечества как вида. Несмотря на то, что многие предложенные ООН меры, впоследствии реализованные на уровне стран, предприятий и даже отдельных домохозяйств доказали свою эффективность, хоть и не в той степени, в которой ожидалось, мы полагаем, что как с позиций международных организаций, так и государств следует уделять больше внимания следующим вопросам:

- диалогу с производителями (будь то государственный или частный сектор) на «языке рынка» для способствования более четкому пониманию ими личных выгод при переводе схемы работы в русло устойчивости и личных потерь при сохранении нерациональных с точки зрения УР моделей, и в долгосрочной, и в краткосрочной перспективе, оказывая помощь с аудитом и подготовкой плана такого перевода, а также улучшая условия для функционирования «зеленых» компаний или компаний, к этому стремящихся, путем предоставления выгодных налоговых ставок, дотаций и технической поддержки;

- развитию научного сектора не только с целью поиска более «зеленых» источников энергии, возможностей сокращения вредных выбросов, методов более рационального использования ресурсов, а также других итоговых решений, но и для разработки концепций их внедрения в реальное производство на уровне «science to business», поощряя поэтапное наблюдение за процессом внедрения более экологичных схем производства и их корректировки, минимизируя тем самым возможные издержки как с позиции времени, так и масштабов для сохранения доходности предприятий;

- просвещению и повышению информированности населения о глобальных вызовах и их последствиях не только для планеты, но и в индивидуальном плане путем внедрения в образование на всех уровнях, независимо от специализации, набора унифицированных учебных курсов и мероприятий, посвященных важности УР (По аналогии с Швецией и Финляндией, где еще с 2003 г. устойчивое развитие было внедрено в школьное образование, в программы детских садов и в образовательные программы для взрослых); выделения средств на проведение подобных мероприятий как в мегаполисах, так и на периферии; поощрения в экономическом или ином плане личных инициатив в сфере УР, для информирования о которых можно разработать доступную как коллективным субъектам, так и отдельным гражданам систе- 
му отчетности; подключения к популяризации идей УР СМИ в роли международных агентств, государственных и иных каналов с федеральным или локальным вещанием, а также агентов влияния в лице лидеров мнения, блогеров, знаменитостей; распространения преимущественно позитивного опыта в плане достижений при реализации ЦУР для повышения мотивированности реципиентов к изменению своих жизненных или производственных позиций (на наш взгляд, доминирующее сегодня освещение концепции УР в ключе алармизма, негативных прогнозов и недостаточности мер подрывает веру общества в проводимую на поприще УР работу и демотивирует его);

- обмену опытом на всех уровнях как внутри стран, так и между ними при создании условий для того, чтобы более успешные с точки зрения реализации ЦУР субъекты, будь то государства, предприятия или отдельные граждане, оказывали помощь менее преуспевающим в этом плане эквивалентным субъектам и за это получали некого рода поощрение в экономическом или ином выражении.

Таким образом, как мы могли убедиться, эволюция взглядов на развитие в ретроспективе разительно менялась: человек воспринимал себя одним из элементов мироздания, единых во всем по своей природе, однако настал момент, когда он решил, что является хозяином мира, который в праве распоряжаться им только ради собственного блага - экономических выгод. Такой подход обеспечил небывалые темпы экономического роста, но нанес сильный удар по окружающей среде: это заставило общество вновь пересмотреть свои взгляды на развитие с учетом важности экологического аспекта, однако к настоящему моменту окончательного перехода к новой жизненной парадигме, предполагающей коэволюцию человека и природы, так и не состоялось в силу прочно укоренившегося в сознании некоторых людей приоритета собственных узких выгод над интересами всего человечества, нынешнего и будущих поколений.

В нашем понимании, для повышения эффективности перевода мирового сообщества из парадигмы сверхпотребления в парадигму УР в целях продвижения этих идей следует использовать «язык» пока еще доминирующей неолиберальной системы, чтобы каждый, помимо осознания общих долгосрочных позитивных тенденций в случае перестройки своего образа жизни в колею устойчивости, понимал и личные выгоды в корреляции с сегодняшним днем. В связи с ориентацией концепции на будущее следует направлять основные усилия на воспитание последующих поколений в контексте принципов УР, прививая их с раннего детства и продолжая укреплять при взрослении. Так будет возможно подготовить новых лидеров, способных в дальнейшем со своих позиций более эффективно решать глобальные проблемы, имея поддержку со стороны общества, «воспитанного» в русле УР. Также следует принять во внимание то, что антропогенные метаморфозы природы не прекратятся в один момент, и даже при самых совершенных мерах 
противодействия им будут сохранять свое влияние на уклад жизни людей еще долгое время, в связи с чем требуют учета при формировании подходов к развитию в будущем. Сегодня мир еще далек от завершения перехода от одной модели развития, породившей множество угроз, к друго - предлагающей способ их устранить, и это противостояние продолжается, однако, как заметил А. Эйнштейн, «ни одна проблема не может быть решена на том же уровне сознание, которое ее породило» [24].

\section{БИБЛИОГРАФИЧЕСКИЙ СПИСОК:}

1. Аддис-Абебская программа действий. 2015 // https://unctad.org/system/ files/official-document/ares69d313_ru.pdf.

2. Бекетова E.Н. Социально-философские основания концепции устойчивого развития в контексте цивилизационного развития // ИСОМ. 2012. № 6.

3. Гаязова C.P. Прогресс как развитие разума и регресс как форма варварства в представлении французских философов эпохи Просвещения // Вестник КазГУКИ. 2015. № 4-2 // https:/cyberleninka.ru/article/n/progress-kak-razvitierazuma-i-regress-kak-forma-varvarstva-v-predstavlenii-frantsuzskih-filosofovepohi-prosvescheniya.

4. Глобальная экологическая перспектива. 2019// https://www.unenvironment. org/ru/resources/globalnaya-ekologicheskaya-perspektiva-6.

5. Да Винчи Л., W. An. В. 82 r., Избранное // Государственное издательство художественной литературы. 1952 // https://www.rulit.me/books/izbrannyeproizvedeniya-read-563787-46.html.

6. Декларация Конференции Организации Объединенных Наций по проблемам окружающей человека среды. Конференция ООН по проблемам окружающей человека среды. 1972 // https:/www.un.org/ru/documents/decl_ conv/declarations/declarathenv.shtml.

7. Денисова Т.Ю. Время и вечность в онтологических моделях Парменида и Гераклита // Идеи и идеалы. 2018. № 4 (38) // https://cyberleninka.ru/ article/n/vremya-i-vechnost-v-ontologicheskih-modelyah-parmenida-i-geraklita.

8. Ильин А.Н. Общество потребления и потребительская инфраструктура // Человек в мире культуры. 2016. № 1 // https://cyberleninka.ru/article/n/ obschestvo-potrebleniya-i-potrebitelskaya-infrastruktura.

9. Ильина Т.А. Философско-гносеологический генезис методологии классической науки // Вестник Московского государственного лингвистического университета. Гуманитарные науки. 2016. № 2 (765) // https://cyberleninka.ru/ article/n/filosofsko-gnoseologicheskiy-genezis-metodologii-klassicheskoy-nauki.

10. Кант И. Метафизические начала учения о добродетели // Сочинения в 4-х т. М.: Мысль, 1965. Т. 4.

11. Конвенция о биологическом разнообразии. 1992 // https://www.un.org/ ru/documents/decl_conv/conventions/biodiv.shtml. 
12. Маркина М.И. Актуальность воззрений Жан-Жака Руссо в условиях экологического кризиса современности // Сборник научных статей студентов РЭУ им. Г.В. Плеханова. По материалам Круглого стола. НОО «Профессиональная наука». 2017.

13. Печатнов B.B. Проблема зла у Августина и Боэция // Вестник ВятГУ. 2017. № 4 // https://cyberleninka.ru/article/n/problema-zla-u-avgustina-i-boetsiya.

14. Рамочная конвенция Организации Объединенных Наций об изменении климата. 1992 // https://www.un.org/ru/documents/decl_conv/conventions/ climate framework conv.shtml.

15. Тихоикая И.С. Экологические проблемы в Японии: между прошлым и будущим // Японские исследования. 2016. № 1 // https:/cyberleninka.ru/ article/n/ekologicheskie-problemy-v-yaponii-mezhdu-proshlym-i-buduschiml.

16. Цели развития тысячелетия Организации Объединенных Наций. 2000 // https://www.un.org/ru/documents/decl_conv/declarations/summitdecl.shtml.

17. A/RES/70/1 - Transforming our world: the 2030 Agenda for Sustainable Development. $2015 / /$ https://www.un.org/ga/search/view_doc.asp?symbol=A/ $\mathrm{RES} / 70 / 1 \&$ Lang $=\mathrm{E}$.

18. Agenda 21, 1992 // https://www.un.org/ru/documents/decl_conv/conventions/agenda21.shtml.

19. Bachmann J., Calkins D., Oge M. Cleaning the Air We Breathe: A Half Century of Progress, 2017 // https://www.epaalumni.org/hcp/air.pdf.

20. Bazić J., Minić $V$. The Global Affects of Scientific-Technological Revolution on the Social Alternations, Informatologia 42, $2009 / /$ https://hrcak. srce.hr/file/64446.

21. Carson R. Silent Spring, Houghton Mifflin Company, 1962.

22. Dowdey S. Greenpeace History // https://money.howstuffworks.com/ greenpeace $2 . \mathrm{htm}$.

23. Ehrlich P. The Population Bomb // Riversity Press, USA: 1975. Vol. 1.

24. Einstein A. Quotes // https://www.brainyquote.com/quotes/albert_einstein 130982.

25. Hall D. Climate explained: why some people still think climate change isn't real. 2019 // https://theconversation.com/climate-explained-why-some-peoplestill-think-climate-change-isnt-real-124763.

26. Hibbard Jr.W.R. Mineral Resources: Challenge or Threat? Science, 1968.

27. Meadows D.H., Meadows D.L., Randers J., Behrens III W.W. The Limits to Growth A Report for the Club of Rome's Project on the Predicament of Mankind. New York: Universe Books, 1972 // https:/archive.org/details/ limitstogrowthr00mead/page/n211/mode/2up.

28. Mesarovic M.D., Pestel E.C. Mankind at the turning point: the second report to the Club of Rome, Club of Rome, 1974 // https://archive.org/details/ mankindatturning00mesa/page/n227/mode/2up.

29.ParisAgreement.2015//https://treaties.un.org/doc/Treaties/2016/02/20160 215\%2006-03\%20PM/Ch_XXVII-7-d.pdf. 
30. Perkins J. Confessions of an economic hit man, Berrett-Koehler Publishers, Inc., San Francisco, 2004.

31. Presidential Proclamation Modifying the Bears Ears National Monument, 2017, White House // https://www.whitehouse.gov/presidential-actions/presidential-proclamation-modifying-bears-ears-national-monument/.

32. Presidential Proclamation Modifying the Grand Staircase-Escalante National Monument, 2017, White House // https://www.whitehouse.gov/ presidential-actions/presidential-proclamation-modifying-grand-staircaseescalante-national-monument/.

33. Report of the World Commission on Environment and Development: Our Common Future, World Commission on Environment and Development, 1987 // https://sustainabledevelopment.un.org/content/documents/5987our-common-future.pdf.

34. SS Jacob Luckenbach Oil Spill, U.S. Department of the Interior // https:// www.cerc.usgs.gov/orda_docs/CaseDetails?ID $=962$.

35. Technical Platform on the Measurement and Reduction of Food Loss and Waste // http://www.fao.org/platform-food-loss-waste/en/.

36. The Great Smog of 1952, Met Office, 2014 // https://web.archive.org/ web/20140903190137/http://www.metoffice.gov.uk/education/teens/casestudies/great-smog.

37. The Sustainable Development Goals Report 2020 // https://unstats.un.org/ sdgs/report/2020/\#.

\author{
A.A. KAPITONOV \\ Working for the degree of the Candidate \\ of political sciences at the Diplomatic Academy of the \\ Ministry of Foreign Affairs of the Russian Federation, \\ Moscow, Russia
}

\title{
CHANGING THE DEVELOPMENT PARADIGM: ENVIRONMENTAL FACTORS IN THE PAST, PRESENT AND FUTURE
}

This article examines the approaches to development that prevailed at different stages of society's formation and the role assigned to the environment in them, analyzes the current transition stage from consumer attitude to nature to the rational use of its resources based on the concept of sustainable development, explains the causes of persistent environmental problems and suggests possible ways to solve them.

Key words: society, sustainable development, global challenges, economic growth, scientific and technological progress, UN, ecology, resources. 